\title{
Constraints to Fertilizer Use in Uganda: Insights from Uganda Census of Agriculture 2008/9
}

\author{
Geoffrey Okoboi ${ }^{1} \&$ Mildred Barungi ${ }^{1}$ \\ ${ }^{1}$ Economic Policy Research Centre, Kampala, Uganda \\ Correspondence: Geofrey Okoboi, Economic Policy Research Centre, Plot 51, Makerere University, P.O. Box \\ 7841, Kampala, Uganda. Tel: 256-752-372-831. E-mail: okoboi@eprc.or.ug
}

Received: August 21, 2012 Accepted: September 25, 2012 Online Published: September 28, 2012

doi:10.5539/jsd.v5n10p99 URL: http://dx.doi.org/10.5539/jsd.v5n10p99

\begin{abstract}
Uganda's agriculture faces numerous challenges, including low productivity due to declining soil fertility. Yet, the majority agricultural households in the country do not use organic and inorganic fertilizers due to not well-known constraints. Using data from the Uganda Census of Agriculture 2008/9, this paper provides insights into these constraints. Results show that most of the farm-households that use inorganic fertilizers also apply organic fertilizers. With regard to factors influencing adoption of fertilizer, lack of knowledge on use of and market information on fertilizer due to limited access to fertilizer-specific extension services is found to be perhaps the most limiting factor irrespective of fertilizer type. Low access to credit and constrained access to input and output markets due to distance are also key constraints to fertilizer use. Household characteristics including education level, household size, share of adults in the household, and ownership of livestock/poultry also stand-out as influencing factors on fertilizer adoption decisions. Results suggest that targeted interventions including extensive and intensive extension training and visits, and access to affordable credit and will be pertinent in the promotion fertilizer use in the country.
\end{abstract}

Keywords: fertilizer use, constraints, Uganda

\section{Introduction}

Food security and nutrition in Uganda remain precarious despite a decade of government interventions - through the Plan for Modernization of Agriculture (PMA) to transform agricultural production from subsistence to modern farming. Ssewanyana and Kasirye (2010) indicate that over two-thirds of the country's population are food insecure, and the number at risk is likely to increase considering the fact that average agricultural production growth for the past five years remains low (about 1.2 percent (\%) per annum) compared to 5-year average population growth of about $3.2 \%$ per annum. The population of Uganda, estimated at 32.9 million in 2011, is projected to grow to 89 million in 2037 (Population Secretariat, 2010). The rapid population growth in the country has led to unprecedented increase in the demand for land for cultivation, food and wood for energy. This has serious implications on agriculture as well as the environment. Henao and Baanante (2006) indicate that approximately $70 \%$ of deforestation in Africa is a result of land clearing for cultivation.

Low productivity, declining soil fertility coupled with low use of improved inputs such as fertilizer, among other factors are cited in the Development Strategy and Investment Plan (2010/11-2014/15) of the Ministry of Agriculture Animal Industry and Fisheries (MAAIF) as one of the key challenges to increasing agricultural output in Uganda (MAAIF, 2010). One way to address the twin problem of low agricultural productivity on one hand and environmental degradation on the other is fertilizer use -both organic and inorganic, especially in low income countries where fertilizer use is lowest (Smaling et al., 2006). Inorganic fertilizer use in grain production, for example, can increase output by $40-60 \%$ (Roberts, 2009). Application of organic fertilizer from animal and/or plant residues on the other hand provide some nutrients besides playing a crucial role in improving soil moisture conservation, especially when combined with conservation tillage practices that protect soil structure, reduce erosion and runoff, and promote soil biological functions important for soil productivity (Agwe et al., 2007). Nonetheless, a combination of organic and inorganic fertilizer for integrated soil fertility management is the most ideal in increasing yield while maintaining long term soil fertility (Alley \& Vanlauwe, 2009).

Indirectly, use of fertilizers lead to higher economic growth and poverty reduction through increased agricultural productivity and output (Dethier \& Effenberger, 2011). This is particularly more evident in Sub-Saharan Africa 
(SSA) countries where agriculture is the primary sector and source of livelihood to the majority of the population (World Bank, 2007). Indeed recent empirical evidence from Uganda (such as Senoga \& Matovu, 2010) has demonstrated that increasing agricultural output and productivity leads to higher growth of the gross domestic product and accelerates poverty reduction. On the environmental front, agricultural intensification - where a farmer gets more output from the same piece of land by using high yielding inputs including fertilizer, reduces forest cover loss and promotes biodiversity (Smaling et al., 2006). Nevertheless, if not well managed, long-term use of fertilizer - whether organic or inorganic, results in inefficiencies of input use, leading to soil degradation, lower productivity and potential damage to the environment (FAO, 1994; Ju et al., 2007).

Despite the benefits, use of fertilizer in crop production in Uganda remains low; at about one kilogram (kg) of inorganic fertilizer per hectare per annum (Pender et al., 2004). This is despite the fact that the country is among those with the highest level of soil nutrient (mainly nitrogen, phosphorous, and potassium) loss in the world (Henao \& Baanante, 2006). Although Uganda is among countries in SSA that signed the Abuja declaration of increasing fertilizer use from the continent average of $8 \mathrm{~kg}$ per hectare to at least $50 \mathrm{~kg}$ per hectare per annum by 2015 (African Union, 2006), there is little indication that the country is about to attain fertilizer use intensity of at least $5 \mathrm{~kg}$ of per hectare per annum. According to Smaling et al. (2006), unless radical interventions occur, projected inorganic fertilizer consumption growth in SSA until 2030 will remain at $1.9 \%$ per annum.

A range of factors -both economic and non-economic, impede adoption of agricultural technologies. In Uganda, however, there is limited evidence regarding what these factors maybe in relation to adoption of fertilizer. This paper uses recent data from Uganda Census of Agriculture (UCA) 2008/9) to examine the factors that have a critical bearing on farmer use of fertilizer in the country. The rest of the paper is structured in four parts. The first part reviews literature on economic and non-economic factors that may influence farmers 'decisions to use agricultural technologies. This is followed by a discussion of the data and methods used. The third part presents and discusses the empirical results. The last section gives the conclusions and policy implications of the findings.

\section{Review of Literature}

Although use of improved technologies including improved seed and fertilizer is essential in increasing agricultural productivity, food security and reducing poverty, not all farmers in agriculture-dependent countries in SSA in general and Uganda in particular, use these inputs. Factors that influence farmers' decisions to use improved technologies can be broadly categorised into economic factors and non-economic factors. Economic factors mainly focus on price, costs and/or returns to factors of production while non-economic factors include social, cultural, institutional and political factors.

\subsection{Economic Factors}

Economic factors that influence fertilizer use among others include the price of fertilizer, price of other inputs that complement (such as seed) or substitute fertilizer use, price of crop output, profit and opportunity costs associated with production and marketing risks. Empirical literature suggests that fertilizer use is sensitive to changes in its price as well as the price of crops to which it is applied (Griliches, 1958; Roberts \& Heady, 1982; Ariga \& Jayne, 2010). In particular, demand for a particular variety/brand of fertilizer (like nitrogen) is derived demand, price elastic and influenced by the price of other varieties/brands of fertilizer (Acheampong \& Dicks, 2012). The price and/or availability of other inputs that complement and enhance fertilizer productivity - for example, hybrid seed and irrigation, also play an important role in farmer's decision to use fertilizer. Similarly, the price and/or availability of other inputs that substitute a variety of fertilizer as well influence its use (Acheampong \& Dicks, 2012).

The wedge between the high price of fertilizer on the one hand and low price of crops on the other, especially for farmers in landlocked countries in SSA is one of the major factors that make them reluctant to use the input. Morris et al. (2007) observe that demand for fertilizer is often weak in Africa because incentives to use fertilizer are undermined by the low level and high variability of crop yields on the one hand and the high level of fertilizer prices relative to crop prices on the other. Smaling et al. (2006) indicate for example that farmers in Africa require $6-11 \mathrm{~kg}$ of grain to purchase one $\mathrm{kg}$ of nitrogenous fertilizer compared with about $2-3 \mathrm{~kg}$ of grain in Asia.

High fertilizer prices in SSA are mostly attributed to high transaction costs of fertilizer trade arising from high transportation costs, high interest rates and low volume of purchases (Gregory \& Bumb, 2006). Lack of market information about the availability and cost of fertilizer and the inability of many farmers to raise the resources needed to purchase fertilizer in bulk is cited among other factors that make farmers pay more for fertilizer (Morris et al., 2007). Low farm-gate prices for crops on the other hand is mainly influenced by poor road 
infrastructure and lack of storage facilities as well as lack of market information (Torero \& Chowdhury, 2004; Morris et al., 2007).

The ability of the farmer to actually buy the input is perhaps the most important characteristic, which hitherto is not well captured in the literature. According to Morris et al. (2007), even if farmers believe that fertilizer is profitable, they may be unable to purchase it if lack cash and/or cannot obtain credit. In agricultural households, the main sources of cash include earnings from salary/wage employment, sell of livestock, and trade. Besides, farm-household size and composition -which has close links with labour supply as well as the income status of the household head, has both positive and negative implications on adoption of inputs. In case of labour intensive inputs such as production and use of organic fertilizer, availability of labour with minimum knowledge can encourage its use even in poor households. On the other hand, if large households are disproportionately poor, then lower use of relatively expensive inputs such inorganic fertilizer is expected in households with large families. As such, the effect of family size and composition on agricultural technology adoption is not clear in adoption literature -as both positive and negative relationships have been reported (Oluoch-Kosura et al., 2001).

\subsection{Non-economic Factors}

Lanyintuo and Mekuria (2005) categorize non-economic factors that influence farmers' decisions to use agricultural improved inputs as: farmer characteristics, institutional factors and characteristics of the input. Farmer characteristics among others include sex, age, education, and household size while institutional factors include farm size, membership to association, access to information, access to credit, and access to infrastructure such as roads or storage. Characteristics of the factor input relate to the subjective attributes of the input as perceived by the farmer (Adesina \& Zinnah, 1993).

Sex plays an important role in farmer use of agricultural technologies. A recent study by Nayenga (2008) indicates that use of agricultural inputs - including inorganic fertilizer in Uganda, is more prevalent in male than female headed households. In Kenya et al. (2010) also found differences in the proportion of men compared to women household heads in Nakuru urban area using fertilizer -though the result was not significant due to sample size. In Malawi where fertilizers are provided to farmers as subsidies irrespective of sex, no significant men/women differences have been observed with regard to use (Chirwa et al., 2011). Lanyintuo and Mekuria (2005) argue for inclusion of sex in analysis of technology adoption by observing that extension services provision, which is important in use of improved inputs, is mainly conducted by men who are biased towards fellow men and yet women are the majority in African agriculture - in particular small-scale agriculture. Additionally, inclusion of sex as one of the explanatory variables is important in the case of Uganda because; women-headed households are relatively poor compared to male-headed households (UBoS, 2010); and yet 72\% of all employed women and $90 \%$ of all rural women work in agriculture (IFAD, 2000).

Studies that have examined the relationship between age and use of improved technologies in production have reported mixed results. Adesina and Baido-Forson (1995) reported a positive relationship between age and adoption of new sorghum and rice varieties in Burkina Faso and Guinea respectively. On the contrary, Kassie et al. (2010) found a negative relationship between age and use of compost manure and stubble tillage in Ethiopia. In Nigeria, several authors (Lawal \& Oluyole, 2008; Akramov, 2009; Tabi et al., 2010) also reported a negative relationship between age and improved inputs use. Explanations offered for the mixed results regarding age and improved inputs use are that on one hand, young farmers may have lower income and wealth, limited access to credit and extension services, and face labour constraints, all of which may make them less prepared to adopt and use improved agricultural technologies than older farmers, hence age having a positive relationship with adoption. On the other hand, young farmers are sometimes more open to change and hence eager to try out new ways of doing things, thus a negative relationship between age and improved inputs use (Lanyintuo \& Mekuria, 2005).

The role of education in farmer use of improved inputs is widely discussed in literature. Educated farmers are believed to have higher ability to perceive, interpret and respond to new information about improved technologies than their counterparts with little or no education (Lanyintuo \& Mekuria, 2005; Tabi et al., 2010). Relatively more educated farmers are more likely to access information and advice from extension workers, which influence their adoption and use of improved inputs. Moreover, education and the economic status of the farmer, which affects ability to buy and use improved inputs, are to a great extent positively correlated especially in developing countries such as Uganda (UBoS, 2010).

The role of credit in financing farmer investments in improved technologies, particularly in developing countries where smallholder farmers are generally financially constrained cannot be overstated. Whereas most studies report a positive relationship between access to credit and use of improved technologies (Feder et al., 1985), a 
recent report by UBoS observes that access to credit in Uganda is a challenge (UBoS, 2010). An earlier study by Deininger and Okidi (2001) reported that financial capital constraints were a major obstacle to fertilizer use in Uganda.

Extension agents are some of the most important sources of agricultural information in many countries. Farmers' access to information on agricultural technologies through increased government investment in extension services is crucial in revealing the opportunities of using such technologies, thereby reducing the subjective uncertainty on one hand and fostering increased adoption on the other (Strauss et al., 1991; Lanyintuo \& Mekuria, 2005). Indeed, a number of studies (Feder \& Slade, 1984; Igodan et al., 1988; Strauss et al., 1991; Deininger \& Okidi, 2001; Akromov, 2009), report a positive relationship between access to extension services and use of improved technologies in general and fertilizer in particular. Nonetheless, the provision of extension services in Uganda is dominated by men who have little or no gender-aware training (Opio, 2003).

Availability of and easy access to infrastructures such as roads, storage and irrigation facilities are critical in agricultural production processes. Roads, for example, ease access to inputs and outputs markets; while storage facilities help to maintain the quality of harvested crops and postpone immediate sale. A number of studies including Jansen et al. (1990) and Ransom et al. (2003) reported that availability of and access to such infrastructure increases the likelihood of use of improved technologies. In Bangladeshi, Ahmed \& Hossain (1990) found that improved rural infrastructure tremendously increased the intensity of use of modern agricultural technologies including fertilizer, high yielding varieties and irrigation, in villages with developed infrastructure than in underdeveloped villages.

According to Morris et al. (2007), factors that influence the intensity of fertilizer use depend on farmers' perceptions of the potential profitability of fertilizer use -which in turn depend on the characteristics of the input, including productivity of (crop response to) fertilizer as well as the perceptions that farmers may hold against fertilizer. Vanlauwe and Giller (2006), for example, catalogue several myths surrounding soil nutrient balances, and organic and inorganic fertilizers use in SSA, which the authors note that potentially limits soil fertility management if not adequately demystified.

\section{Data and Methods}

\subsection{Data}

The paper draws on UCA 2008/9 data to achieve the set objectives. The Census was conducted by UBoS from September 2008 to August 2009, in all the 80 districts that existed in the country in July 2007 -which was the planning time of the survey (UBoS, 2008). Data were collected on three modules, namely: (i) The Agricultural Household and Holding Characteristics Module; which was used to collect data on the demographic characteristics of household members as well as structural type of data on the agricultural holding; (ii) Crop area module captured information on holding parcel and crop plot areas; and (iii) Crop Production Module; which collected data on crop production. Households were visited twice during the survey period (UBoS, 2008).

According to the UCA 2008/9 technical report, data was collected through a sampling scheme of 3,606 Enumeration Areas (EAs) and 10 agricultural households in each selected EA. In total, 31,340 agricultural households were sampled. Our analysis is however restricted to 29,355 households that had non-missing information on whether they applied fertilizers. A quick exploratory data analysis of the variables used in this study revealed some missing data. In survey data, missing data is a common problem because some respondents do not answer some questions (Carlson et al., 1995). Missing data are a potential source of bias in the analysis, especially if the variable with missing data is essential in the results outcome (EMEA, 2001).

Suggestions to deal with key data items missing in the analysis are provided in the literature. One suggestion is to drop respondents with missing data in the analysis and adjust the weighting process, while the other is to impute or substitute a valid response for the missing value (Carson et al., 1995). Kalton (1995) and Engels and Diehr (2003) provide thorough discussions of approaches for imputation of missing values in cross-sectional survey data and longitudinal data, respectively, including deterministic (e.g. mean, median or modal values) and stochastic (e.g. random regressions) approaches. Of all the approaches, none is a gold standard, though deterministic approaches are rather common. Given that missing data in some of the variables in this paper were fairly high, median values were calculated and substituted for missing data (Table 1).

\subsection{Model Specification}

Farmer $i$ can decide to use two different, but interrelated fertilizers in crop production. That is organic fertilizer $\left(\mathrm{Y}_{1}\right)$ and/or inorganic fertilizer $\left(\mathrm{Y}_{2}\right)$. When decisions by the same actor are discrete and interrelated/joint, 
bivariate probit or logit models are appropriate (Greene, 2002). The two probit models for $Y_{1}$ and $Y_{2}$ are presented in Equation 1 and 2, respectively

$$
\begin{gathered}
Y_{1 \mathrm{i}}^{*}=X_{1 \mathrm{i}} \beta_{1}+u_{1 \mathrm{i}} \text {, where } Y_{1 \mathrm{i}}=1 \text { if } Y_{1 \mathrm{i}}^{*}>0 ; 0 \text { otherwise } \\
Y_{2 \mathrm{i}}^{*}=X_{2 \mathrm{i}} \beta_{2}+u_{2 \mathrm{i}} \text {, where } Y_{2 \mathrm{i}}=1 \text { if } Y_{2 \mathrm{i}}^{*}>0 ; 0 \text { otherwise }
\end{gathered}
$$

Where $Y_{1}\left(Y_{1}^{*}\right)$ and $Y_{2}\left(Y_{2}^{*}\right)$ are the observed (latent) binary variables indicating the use/non-use of organic and/or inorganic fertilizer. The explanatory variables are given by the vectors $X_{1}$ and $X_{2}$ while $\beta_{1}$ and $\beta_{2}$ are the unknown parameters of the respective equations, to be estimated.

Since the outcomes $Y_{1}$ and $Y_{2}$ are interrelated, the error terms $u_{1 i}$ and $u_{2 i}$, representing unobservable factors that influence fertilizer adoption are correlated and hence not independent of one another. That is $\operatorname{Cov}\left(u_{1 i}, u_{2 i}\right) \neq 0$ Estimation of Equations 1 and 2 separately using a simple probit model yields biased estimates (Greene, 2002). The bivariate probit estimation technique yields consistent and efficient estimates -as the model assumes the error terms $u_{1 \mathrm{i}}$ and $\mathrm{u}_{2 \mathrm{i}}$-though jointly normally distributed, are correlated. (Greene, 2002). In this paper, the correlation coefficient $(\rho)$ is estimated and is different from zero (Table 4), implying dependence in the two equations.

In bivariate probit model estimation, the explanatory variables $X_{1}$ and $X_{2}$ are one and the same. In a reduced form, Equations 1 and 2 are written as:

$$
\begin{gathered}
\mathrm{Y}_{1 \mathrm{i}}=\mathrm{X}_{\mathrm{i}} \beta_{1}+\mathrm{u}_{1 \mathrm{i}} \\
\mathrm{Y}_{2 \mathrm{i}}=\mathrm{X}_{\mathrm{i}} \beta_{2}+\mathrm{u}_{2 \mathrm{i}}
\end{gathered}
$$

Where, $\mathrm{X}$ is a vector of explanatory variables including farmer characteristics, institutional and market access factors. Details of these variables follow in the next section.

\subsection{Description of Variables}

\subsubsection{Dependent Variable}

The dependent variable is whether or not a household used fertilizers (organic and/or inorganic) in agricultural production in 2008/9. Summary statistics of these variables, provided in Table 1, indicate that about $26 \%$ of households reported using organic fertilizers while $8 \%$ reported using inorganic fertilizers. However, these variables could not be used to provide insights on intensity of usage. Lack of information on the quantity and cost of fertilizers applied limit our ability to provide policy guidance on what government needs to do to increase application of fertilizers as per the recommended rates or the commitments made in Abuja declaration.

\subsubsection{Explanatory Variables}

Ideally, economic factors to be included in this study would comprise price, cost and quantities of inputs/outputs. Nonetheless, these were not captured in the UCA 2008/9. Instead, we include distance to market (for farm-input shops and produce), and distance to all-year gravel roads as proxies for cost of inputs and price/value of outputs. These factors can also be regarded as market access variables. Households who are more distant from these facilities are hypothesized to less likely use fertilizers. Descriptive statistics of these variables are also provided in Table 1.

Non-economic variables included in this paper are household characteristics, production support services and location (regional) factors. Household characteristics include those of the head of the household in terms of age, sex, marital status, and education attainment. Other variables included household size, share of adult members in the household, and ownership of livestock/poultry. Our hypothesis is that household heads with more years of education, and/or own livestock/poultry are more likely to use fertilizers - both organic and inorganic.

Production support factors included are: access to extension services, access to credit, ownership of storage facility, ownership of irrigation facility. It is hypothesised that households who access/own of these services/facilities are more likely to apply fertilizers. Regional dummies are included to account for differences that might arise due to geography, soil types, crop patterns, culture, and socio-economic status. The units of measurement and summary statistics of these variables are presented in Table 1. 
Table 1. Summary statistics of variables used in the analysis

\begin{tabular}{|c|c|c|c|}
\hline Variables & Unit of measure & Mean & Std. Err. \\
\hline \multicolumn{4}{|l|}{ Dependent variables } \\
\hline Organic fertilizer use & Yes $=1, \mathrm{No}=0$ & 0.26 & 0.01 \\
\hline Inorganic fertilizer use & Yes $=1$, No $=0$ & 0.08 & 0.00 \\
\hline \multicolumn{4}{|l|}{ Explanatory variables } \\
\hline Household head age & Years & 44.89 & 0.13 \\
\hline Sex of household head & Male $=1$, female $=0$ & 0.79 & 0.00 \\
\hline Marital status -Single & Yes $=1$, No $=0$ & 0.04 & 0.00 \\
\hline Marital status -married & Yes $=1$, No $=0$ & 0.74 & 0.00 \\
\hline Marital status -separated/divorced/widow & Yes $=1$, No $=0$ & 0.22 & 0.00 \\
\hline Household head years of education & Years & 5.19 & 0.04 \\
\hline Share of adult in household & $\begin{array}{l}\text { Ratio }=\text { adults }(15-59 \\
\text { years }) / \text { household size }\end{array}$ & 0.47 & 0.00 \\
\hline Household size & Number & 5.41 & 0.03 \\
\hline Household keeps livestock/poultry & Yes $=1$, No $=0$ & 0.70 & 0.01 \\
\hline Household head access to extension services & Yes $=1$, No $=0$ & 0.19 & 0.01 \\
\hline Household head access to credit & Yes $=1$, No $=0$ & 0.10 & 0.00 \\
\hline Household has storage facility & Yes $=1$, No $=0$ & 0.56 & 0.01 \\
\hline Household has irrigation equipment & Yes $=1$, No $=0$ & 0.01 & 0.00 \\
\hline Distance to market & Kilometres & 20.03 & 0.36 \\
\hline Distance to all-year gravel road & Kilometres & 4.19 & 0.16 \\
\hline Household in Central region & Yes $=1$, No $=0$ & 0.20 & 0.01 \\
\hline Household in Eastern region & Yes $=1$, No $=0$ & 0.30 & 0.01 \\
\hline Household in Northern region & Yes $=1$, No $=0$ & 0.20 & 0.01 \\
\hline Household in Western region & Yes $=1$, No $=0$ & 0.29 & 0.01 \\
\hline \multicolumn{4}{|c|}{ Missing value- variables (proportion observed and median value } \\
\hline Variable & Missing value & proportion & Median \\
\hline Household head age (years) & Yes $=1$, No $=0$ & 0.02 & 42.32 \\
\hline $\begin{array}{l}\text { Marital status(either single, married, or } \\
\text { separated/divorced/widow }\end{array}$ & $\mathrm{Yes}=1, \mathrm{No}=0$ & 0.06 & 0.5 \\
\hline Household head years of education (years) & Yes $=1, \mathrm{No}=0$ & 0.01 & 6 \\
\hline Distance to market (kilometres) & Yes $=1$, No $=0$ & 0.17 & 15 \\
\hline Distance to All-year gravel road (kilometres) & Yes $=1$, No $=0$ & 0.21 & 2 \\
\hline
\end{tabular}

\subsection{Model Estimation}

The bivariate probit model is estimated by the maximum likelihood method. The estimated coefficients of the regression are reported as marginal effects.

Explanatory variables with continuous values were transformed into natural logarithms to make the data normally distributed and/or their variances homogenous (McDonald, 2009). In particular, values of the following variables: years of education, distance to market, and distance all-year gravel road, were transformed into natural logarithms. 


\section{Results and Discussions}

\subsection{Descriptive Statistics}

Key characteristics of agricultural households that use fertilizers are shown in Table 2. It is evident from the table that households that use fertilizers regardless of type are headed by better educated persons; male heads and have relatively large families. The difference in the mean values is statistically significant $(p<0.01)$. No mean differences in age are found with regard to household head use of inorganic fertilizer. It is further noted that households that used inorganic fertilizer had a higher proportion of adults (15-59 years) relative to their counterparts that did not use inorganic fertilizer.

Table 2. Agricultural household head characteristics of users and non-users of fertilizers

\begin{tabular}{|c|c|c|c|c|c|c|}
\hline & \multicolumn{3}{|c|}{ Organic fertilizer } & \multicolumn{3}{|c|}{ Inorganic fertilizer } \\
\hline & Users & Non-users & $\begin{array}{c}\text { Mean } \\
\text { Difference }\end{array}$ & Users & Non-users & $\begin{array}{c}\text { Mean } \\
\text { Difference }\end{array}$ \\
\hline Age (years) & 45.7 & 44.5 & $1.2 * * *$ & 44.8 & 44.8 & 0.0 \\
\hline $\begin{array}{l}\text { Years of schooling } \\
\text { (years) }\end{array}$ & 5.8 & 5.0 & $0.8 * * *$ & 6.2 & 5.1 & $1.2 * * *$ \\
\hline Male headed (\%) & 75.3 & 65.7 & $9.6 * * *$ & 77.6 & 67.2 & $10.4^{* * *}$ \\
\hline Household size (number) & 5.8 & 5.4 & $0.4 * * *$ & 6.0 & 5.4 & $0.6 * * *$ \\
\hline $\begin{array}{l}\text { Share of adults in } \\
\text { household (\%) }\end{array}$ & 46.1 & 46.3 & -0.2 & 47.4 & 45.3 & $2.1 * * *$ \\
\hline
\end{tabular}

Note: $* * * * *$, and $*$ indicate statistical significance at 1,5 and $10 \%$ level.

Taking sex into consideration, we find that there are more men than women using fertilizers (Table 3). Remarkable differences with regard to use of fertilizers - in favour of households that have access to extension services, credit, had irrigation facilities and/or storage is observed. For example, 15.8\% farm-households that access credit used inorganic fertilizers compared to only $7.7 \%$ who reported using inorganic fertilizer even without credit support. This suggests that access to credit eases the cash constraints and as such enables farmers to afford fertilizers. Fertilizers, regardless of type are used mostly by farmers who own livestock than those who do not. People who own livestock in Uganda are wealthier compared to those without (MoFPED, 2004). This is because livestock is an asset that can be used to generate income and thus can aid farmers to purchase fertilizers. Also, livestock waste (dung and urine) is an important source of organic fertilizers. The incidence of fertilizer use among farmers with irrigation facilities $(31 \%)$ was higher than the proportion of fertilizer users without access to irrigation facilities $(8.3 \%)$.

Table 3. Agricultural households' users (\%) of fertilizers by key complementary factors

\begin{tabular}{|c|c|c|c|}
\hline & \multirow{2}{*}{ Status } & \multicolumn{2}{|c|}{ Fertilizer use } \\
\hline & & Organic & Inorganic \\
\hline \multirow[t]{2}{*}{ Sex } & Male & 26.5 & 9.2 \\
\hline & Female & 24.0 & 6.0 \\
\hline \multirow[t]{2}{*}{ Accesses extension services } & Yes & 35.8 & 12.6 \\
\hline & No & 23.6 & 7.6 \\
\hline \multirow[t]{2}{*}{ Access to credit } & Yes & 40.1 & 15.8 \\
\hline & No & 24.3 & 7.7 \\
\hline \multirow[t]{2}{*}{ Has storage facilities } & Yes & 28.0 & 9.2 \\
\hline & No & 23.3 & 7.7 \\
\hline \multirow[t]{2}{*}{ Has irrigation } & Yes & 50.3 & 31.0 \\
\hline & No & 25.7 & 8.3 \\
\hline \multirow[t]{2}{*}{ Has Livestock/poultry } & Yes & 29.0 & 9.9 \\
\hline & No & 19.0 & 5.4 \\
\hline
\end{tabular}


Of the households that reported access to agricultural extension services, about $30 \%$ received advice on organic/inorganic fertilizer use (Figure 1). Most farmers received advice on agronomic practices and seed variety.

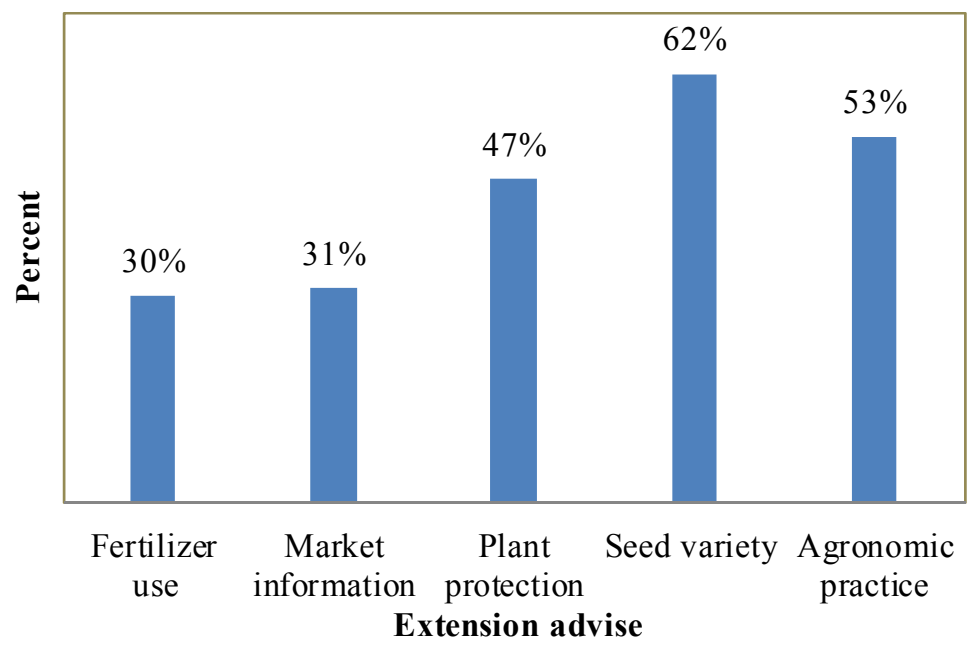

Figure 1. Share (\%) of agricultural households that received extension services on fertilizer use

Regarding sources of fertilizer, most households obtained organic fertilizer from own farms while the market was the main source for inorganic fertilizers (Figure 1). This is expected. What is not clear however is why households ranked on-farm (33\%) as the second most important source of inorganic fertilizer yet it is well known that all inorganic fertilizers used in Uganda are imported. Cooperatives including informal associations of farmers were ranked third (13.7\%) as the most important of source of inorganic fertilizer. This may be due the fact that farmer associations are the entry point through which government programmes such as the NAADS programme and Non-government organizations (NGOs) support farmers with free/subsidized inputs including fertilizers (Mwaura et al., 2011).

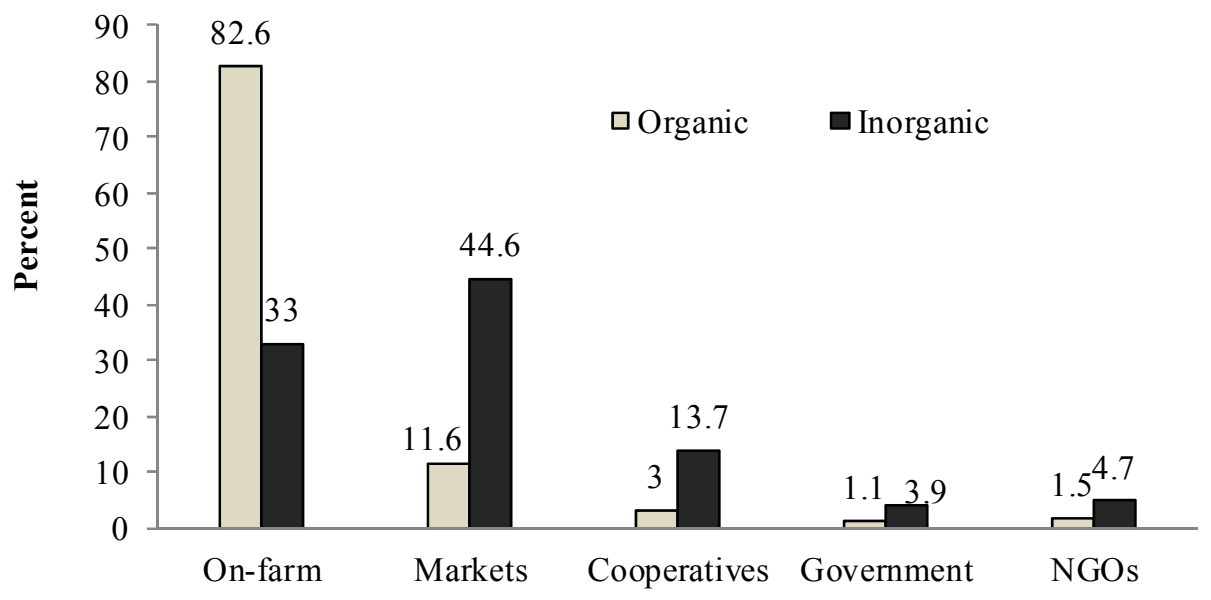

\section{Source of fertilizer}

Figure 2. Agricultural household's most important source (\%) of fertilizers

Turning to reasons for non-use of fertilizers, the most frequently $(50 \%)$ cited reason for not using inorganic fertilizers was that they are too expensive (Figure 3). Other farm-households were not using inorganic fertilizers because they lacked knowledge about them (25\%); lacked access $(14.1 \%)$; while others perceived inorganic fertilizers as being useless $(9.5 \%)$. Similar patterns are observed for non-use of organic fertilizers; notably, lack 
of knowledge for example about on-farm preparation of compost and high cost, for example in case of purchasing compost manure mainly from urban areas.

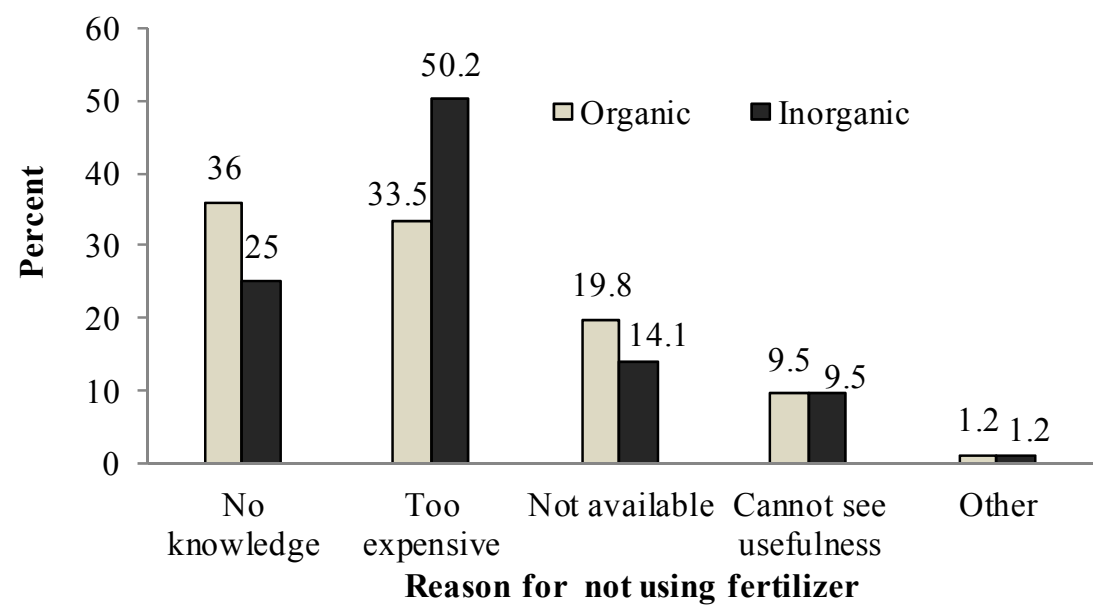

Figure 3. Agricultural households' reasons (\%) on for non-use of fertilizers

\subsection{Econometric Results}

Results of the bivariate probit regression are presented in Table 4 . The estimated correlation coefficient $(\rho)$ is 0.37 and statistically significant $(\mathrm{p}<0.01)$, which indicates that farmers compliment inorganic with organic fertilizers rather than substitute one for the other. Ollowing the fact that organic and/or inorganic fertilizer use is correlated, the estimated coefficients for the two equations are also closely related in magnitude and statistical significance, except for few instances.

Results in Table 4 generally mirror the descriptive statistics and confirm most of our hypotheses. For example, results reveal a strong and statistically significant $(p<0.001)$ relationship between access to extension services and/or credit and fertilizer use irrespective of type - which supports various literatures (Feder \& Slade, 1984; Igodan et al., 1988; Strauss et al., 1991; Akromov, 2009). A similar relationship is observed in the case of ownership of irrigation facility and/or livestock, and fertilizer use. Much as these complementary inputs in production are important in the decision of farmers to adopt fertilizer, the challenge is the availability of these inputs/services in the country. Extension services outreach in Uganda is low (19\%) (see Table 1) and skewed to NAADS supported farmers. Credit on the other hand attracts high interest rates and hence mainly provided to non-agricultural enterprises that have a short gestation period, while use of irrigation in Uganda is in its infancy.

The other factor with a positive influence on fertilizer adoption is the level of education. That is, the prospects to use fertilizer are $2 \%$ higher for farmers with an additional year of education. The likely reason for a higher proportion of more educated farmers using inorganic fertilizer is the fact that more educated people in Uganda have higher disposable income (UBoS, 2010), which makes it possible for them to purchase high-value inputs such as inorganic fertilizer. Besides, more educated farmers are more likely to use fertilizer due to their relatively advantaged position in terms of access to market information and technical advice on agricultural technologies (Langyintuo \& Mekuria, 2005). Despite the importance of high education in fertilizer adoption, the challenge though is that fewer farmers in Uganda, especially women (less than $30 \%$ ) have attained at least secondary education (UBoS, 2010).

Although household size is important in adoption of fertilizer, we note that the share of adults in the household -which is the source of labour, is critical. Taking other factors as constant, up-to $4 \%$ increase in the probability of farmer use of fertilizer both organic and inorganic can be attributed to a unit increase in the proportion of adults in the household. This finding supports literature (for example, Palm et al., 1997) that suggests the availability of labour as a precondition for adoption of bulky inputs such as fertilizer. This is true given the fact that fertilizer use, particularly organic manure production and application is labour intensive. Inorganic fertilizer application/placement at the base of plants rather than broadcasting/sowing, similarly, is labour-intensive. 
Table 4. Bivariate probit model estimates of determinants of use of organic and inorganic fertilizers

\begin{tabular}{|c|c|c|c|c|}
\hline \multirow{2}{*}{ Explanatory variables } & \multicolumn{2}{|l|}{ Organic fertilizer } & \multicolumn{2}{|c|}{ Inorganic fertilizer } \\
\hline & Marginal effect & Z-stat & Marginal effect & Z-stat \\
\hline \multicolumn{5}{|l|}{ Household/head characteristics } \\
\hline Age & $0.000 * * *$ & 6.11 & $0.000 * * *$ & 3.43 \\
\hline Sex $($ male $=1)$ & $-0.002 * * *$ & -2.54 & 0.002 & 1.3 \\
\hline \multicolumn{5}{|l|}{ Marital status (ref $=$ never married) } \\
\hline Married & $0.002 * * *$ & 2.47 & 0.003 & -0.55 \\
\hline Separated/widow/divorced & -0.004 & 0.43 & -0.004 & -0.84 \\
\hline Education years $(\log )$ & $0.015^{* * *}$ & 7.1 & $0.016^{* * *}$ & 7.18 \\
\hline Adults in household (share) & $0.037 * * *$ & 4.22 & $0.04 * * *$ & 6.63 \\
\hline Household size (number) & $0.003 * * *$ & 5.58 & $0.003 * * *$ & 5.22 \\
\hline \multicolumn{5}{|l|}{ Institutional/market access factors } \\
\hline Extension services access $(\mathrm{Yes}=1)$ & $0.029 * * *$ & 12.17 & $0.032 * * *$ & 6.37 \\
\hline Access credit $(\mathrm{Yes}=1)$ & $0.042 * * *$ & 7.72 & $0.045^{* * *}$ & 9.27 \\
\hline Has storage (Yes=1) & $0.007 * * *$ & 6.76 & 0.008 & 0.69 \\
\hline Has irrigation facility $(\mathrm{Yes}=1)$ & $0.138 * * *$ & 5.92 & $0.144 * * *$ & 8.14 \\
\hline Has livestock/poultry $(\mathrm{Yes}=1)$ & $0.026 * * *$ & 11.96 & $0.028 * * *$ & 7.23 \\
\hline Distance to market $(\log )$ & $-0.01 * * *$ & -8.87 & $-0.011 * * *$ & -4.5 \\
\hline Distance to all-year road $(\log )$ & $-0.007 *$ & -1.79 & $-0.007 * * *$ & -3.93 \\
\hline \multicolumn{5}{|l|}{ Region dummies (ref $=$ Central) } \\
\hline Eastern & $-0.025 * * *$ & -16.59 & $-0.030 * * *$ & -3.42 \\
\hline Northern & $-0.05 * * *$ & -28.6 & $-0.057 * * *$ & -12.12 \\
\hline Western & -0.024 & 0.05 & $-0.024 * * *$ & -8.52 \\
\hline No. Obs. & 28550 & & & \\
\hline Wald chi2 & $2530.53 * * *$ & & & \\
\hline Rho $(\rho)$ & 0.3687 & & 0.340 & \\
\hline athrho & $0.387 * * *$ & 23.41 & & \\
\hline Wald chi square test of $\rho=0$ & $548.04 * * *$ & & & \\
\hline
\end{tabular}

Notes: log. implies natural logarithm of the variable. Z-statistics in parenthesis based on robust standard errors. ***, **, and * indicate statistical significance at 1,5 and $10 \%$ level.

Turning to sex, results indicate that female farm-household heads have a higher likelihood than male farm-household heads when it comes to the use of organic fertilizer - which is somewhat contrary to the descriptive result in Table 3. Nonetheless, it appears that the somewhat weaker position of women in Uganda in relation to financial resources (UBoS, 2006; 2010) and supportive extension services (Opio, 2003; Nayenga, 2008) to use inorganic fertilizer might have led them to embrace organic fertilizer as the alternative. Distance to market (input and output markets) as well as distance to all-weather gravel road is observed to negatively influence fertilizer use. This is expected and stands out as critical constraints to rural farm-household in Sub-Saharan Africa, for which Uganda is not an exception.

As with regions, a significantly lower use of organic fertilizer is noted in Eastern and Northern Uganda and lower use of inorganic fertilizer observed in Northern and Western Uganda, compared to Central Uganda, the reference region. Low population of livestock - a major source of manure, in Eastern and Northern Uganda compared to Central and Western regions may be a key constraint to intensive use of organic manures in those regions. Acceptability and practical application of organic manures on large-scale basis by local farmers in 
Uganda however remains a challenge - as many farmers practicing organic based systems take animal refuse to back-yard gardens as a means of disposal rather than as a conscious method of soil nutrient management. Generally, farmers are reluctant to change from familiar methods of soil nutrient management to newer methods (Omotayo \& Chukwuka, 2009).

\section{Conclusions and Implications for Policy}

Lack of or inadequate access to extension services that provide technical advice is a major constraint to increased adoption of fertilizer in Uganda as less than one-fifth of agricultural households receive extension services. Of these, only one-third receive advice on fertilizer use. Owing to the fact that access to extension services increases the likelihood of fertilizer use as well associated agricultural productivity, we propose that government should consider reallocating away the huge resources meant for providing free inputs to few beneficiaries under the National Agricultural Advisory Services (NAADS) programme, to cater for and increase and intensify of extension services delivery to more farmers in the country.

There is a notable bias in fertilizer use based on the sex of the head of the agricultural household. That is, households with female heads are less likely to use inorganic fertilizers compared to their male counterparts. Literature suggests that provision of extension services in Uganda is dominated by male workers who focus their services mostly to fellow men as a result of lack of gender-aware training background. One way of addressing this challenge is to encourage agricultural training institutions to integrate gender-aware training modules in the curriculum. Besides, we suggest that government should deliberately target to train and deploy more female extension workers in the country.

Fertilizer use, access to credit and use of irrigation are closely linked - yet, in Uganda, farm-household access to these complementary services is low. Therefore, any successful intervention to promote fertilizer use in Uganda will have to be accompanied with complementary inputs and services - as a package. While access to credit has a positive influence on fertilizer adoption, it is still expensive and inaccessible to most agricultural households. Government should consider and implement the President's 2011 election plan of providing these households with loans at low interest rates. In particular, government can spur fertilizer adoption by conditioning fertilizer purchase and use on access to affordable agricultural credit, for example through Savings and Credit Co-operatives.

Few farmers in Uganda own/use irrigation facilities yet fertilizer use is more effective with irrigation. For the past five years government has implemented water for production programme targeting mainly rehabilitation large-scale irrigation schemes at the expense of small-scale irrigation for smallholder farmers -who produce most of the country's output and need irrigation water most. Thus we propose that government should consider and review the water for production programme with a view of putting more resources in low-cost small-scale irrigation systems and technical advice to smallholder farmers to adopt irrigation farming on a sustainable basis.

\section{Acknowledgements}

The authors are heavily indebted to Sarah Ssewanyana and two anonymous reviewers for very useful comments on the earlier versions of this paper. We thank the Alliance for a Green Revolution in Africa for financial support.

\section{References}

Acheampong, K., \& Dicks, M. R. (2012). Fertilizer Demand for Bio-fuel and Cereal crop Production in the United States. Paper presented at the Southern Agricultural Economics Association Annual Meeting, Birmingham, Alabama, February 4-7, 2012. Retrieved from http://econpapers.repec.org/paper/agssaea12/119798.htm

Adesina, A., \& Baidu-Forson, A. (1995). Farmers' Perception and Adoption of New Agricultural Technology: Evidence from Analysis in Burkina Faso and Guinea, West Africa. Agricultural Economics, 13, 1-9. http://dx.doi.org/10.1016/0169-5150(95)01142-8

Adesina, A. A., \& Zinnah, M. (1993). Technology Characteristics, Farmers Perceptions, and Adoption Decisions: A Tobit Model Application in Sierra Leone. Agricultural Economics, 9, 297-311. http://dx.doi.org/10.1016/0169-5150(93)90019-9

African Union. (2006). Africa fertilizer summit: Abuja Declaration on Fertilizer for the African Green Revolution. African union Special Summit of the Heads of State and Government. Retrieved from www.afdb.org/en/topics-and-sectors/initiatives-partnerships/african-fertilizer-financing-mechanism/abuja-d eclaration/ 
Agwe, J., Morris, M., \& Fernandes, E. (2007). Africa's Growing Soil Fertility Crisis: What Role for Fertilizer? Agriculture and Rural Development Notes (21), the World Bank. Retrieved from http://siteresources.worldbank.org/INTARD/Resources/fertilizernote.pdf

Ahmed, R., \& Hossain, M. (1990). Developmental Impact of Rural Infrastructure in Bangladesh. Research Report 83. Washington, D. C.: International Food Policy Research Institute (IFPRI).

Akramov, T. K. (2009). Decentralization, Agricultural Services and Determinants of Input Use in Nigeria. Discussion Paper 0094, IFPRI. $\quad$ Retrieved from www.ifpri.org/sites/default/files/publications/ifpridp00941.pdf

Alley, M. M., \& Vanlauwe, B. B. (2009). The Role of Fertilizers in Integrated Plant Nutrient Management. Paris, France: International Fertilizer Association. Retrieved from www.fertilizer.org/ifacontent/.../2/file/2009_ifa_role_plant_nutrients.pdf

Ariga, J., \& Jayne, T. S. (2010). Factors Driving the Increase in Fertilizer Use by Smallholder Farmers in Kenya, 1990-2007. Retrieved from http://siteresources.worldbank.org/AFRICAEXT/Resources/2586431271798012256/Kenya_fertilizer_june_ 2010.pdf

Asfaw, S., Shiferaw, B., Simtowe, F., \& Haile, M. G. (2011). Technology Adoption, Seed Access Constraints and Commercialization in Ethiopia. Journal of Development and Agricultural Economics, 3(9), 436-447. Retrieved from http://www.academicjournals.org/JDAE

Bekunda, M. A., \& Woomer, P. L. (1996). Organic Resource Management in Banana-based Cropping Systems of the Lake Victoria Basin, Uganda. Agriculture, Ecosystems and Environment, 59, 171-180. http://dx.doi.org/10.1016/0167-8809(96)01057-2

Binswanger, H. P. (1980). Attitudes towards Risk: Experimental Measurement in Rural India. American Journal of Agricultural Economics, 62(3), 395-407. http://dx.doi.org/10.2307/1240194

Carlson, B. L., Cox B. G., \& Bandeh, L. S. (1995). SAS Macros Useful in Imputing Missing Survey Data. Princeton, New Jersey: Mathematica Policy Research Inc. Retrieved from http://mathematica.mpr.org/publications/PDFs/misssurdata.pdf

Chirwa, E. W., Mvulaa, P. M., Dor ward, A., \& Matita, M. (2011). Gender and Intra-Household Use of Fertilizers in the Malawi Farm Input Subsidy Programme. Working Paper 28, Future Agricultures. Retrieved from http:// www.future-agricultures.org

Deininger, K., \& Okidi, J. (2001). Rural Households: Incomes, Productivity, and Nonfarm Enterprises. In Reinikka, R., \& Collier, P. (Eds.), Uganda's Recovery: The Role of Farms, Firms, and Government, 123 175. Kampala, Uganda: Fountain Publishers.

Dethier, J. J., \& Effenberger, A. (2011). Agriculture and Development: A Brief Review of the Literature. Development Economics Research Support Unit Working paper 553: The World Bank. Retrieved from http://www-wds.worldbank.org/../WPS5553.pdf

EMEA (The European Agency for the Evaluation of Medicinal Products). (2001). Points to Consider on Missing Data.

Retrieved

from http://www.ema.europa.eu/docs/en_GB/document_library/Scientific_guideline/2009/09/WC500003641

Engels, J. M., \& Diehr, P. (2003). Imputation of missing longitudinal data: a comparison of methods. Journal of Clinical Epidemiology, 56, 968-976. http://dx.doi.org/10.1016/S0895-4356(03)00170-7

FAO (Food and Agriculture Organisation of the United Nations). (1994). Cherish the Earth: Soil Management for Sustainable Agriculture and Environmental Protection in the Tropics. Retrieved from http://ces.iisc.ernet.in/energy/HC270799/LM/SUSLUP/FAO/CHRSHNGL.PDF

FAO. (2006). Fertilizer Use by Crop. Fertilizer and Plant Nutrition Bulletin 17. Retrieved from ftp://ftp.fao.org/docrep/fao/009/a0443e/a0443e00.pdf

FAO. (2010). Gender dimensions of agricultural and rural employment: Differentiated pathways out of poverty. Retrieved from www.fao.org/docrep/013/i1638e/i1638e.pdf

Feder, G., \& Slade, R. (1984). The Acquisition of Information and Adoption of New Technology. American Journal of Agricultural Economics, 66, 312-320. http://dx.doi.org/10.2307/1240798 
Feder, G., Just, R. E., \& Zilberman, D. (1985). Adoption of Agricultural Innovations in Developing Countries: A Survey. Economic Development and Cultural Change, 33(2), 255-298. http://dx.doi.org/10.1086/451461

Greene, W. H. (2002). Econometric Analysis, (5nd ed). Upper Saddle River, New Jersey: Pearson Education Inc.

Gregory, D. I., \& Bumb, B. L. (2006). Factors Affecting Supply of Sub-Saharan Fertilizer in Africa. Agriculture and Rural Development Discussion Paper 24, Washington, D. C.: The World Bank.

Griliches, Z. (1958). The Demand for Fertilizer: An Economic Interpretation of a Technical Change. Journal of Farm Economics, 40, 591-606. http://dx.doi.org/10.2307/1235370

Hazell, P. B. R. (2009). The Asian Green Revolution. Washington, D. C.: IFPRI. Retrieved from www.ifpri.org/sites/default/files/publications/ifpridp00911.pdf

Henao, J., \& Baanante, C. (2006). Agricultural Production and Soil Nutrient Mining in Africa: Implications for Resource Conservation and Policy Development. Muscle Shoals, AL. International Fertilizer Development Center.

IFAD (International Fund for Agricultural Development). (2000). Gender Strengthening Programme for East and Southern Africa; Uganda: Field Diagnostic Study. Retrieved from www.ifad.org/gender/learning/role/labour/54.htm

Igodan, C. O., Ohaji, P. E., \& Ekpere, J. A. (1988). Factors Associated with the Adoption of Recommended Practice for Maize Production in the Kainji Lake Basin of Nigeria. Agricultural Administration and Extension, 29, 149-156. http://dx.doi.org/10.1016/0269-7475(88)90013-X

Jansen, H. G. P., Walker, T. S., \& Barker, R. (1990). Adoption Ceilings and Modern Coarse Cereal Cultivars in India. American Journal of Agricultural Economics, 72(3), 653-663. http://dx.doi.org/10.2307/1243035

Ju, X. T., Kou, C. L., Christie, P., Dou, Z. X., \& Zhang, F. S. (2007). Changes in the Soil Environment from Excessive Application of Fertilizers and Manures to Two Contrasting Intensive Cropping Systems on the North China Plain". Environmental Pollution, 145(2), 497-506. Retrieved from http://dx.doi.org/10.1016/j.envpol.2006.04.017

Kalton, G., \& Kasprzyk, D. (1995). The Treatment of Missing Survey Data. Journal of Official Statistics, 11, 181-204.

Karanja, N., Njenga, M., Gathuru, K., Karanja, A., \& Munyao, P. M. (2010). Crop-Livestock-Waste Interactions in Nakuru Urban Agriculture. African Urban Harvest, 213-228.

Kassie, M., Zikhali, P., Manjur, K., \& Edwards, S. (2010). Adoption of Organic Farming Technologies: Evidence from a Semi-Arid Region in Ethiopia. Rome: FAO.

Langyintuo, A., \& Mekuria, M. (2005). Modeling Agricultural Technology Adoption Using the Software STATA. CIMMYT-ALP Training Manual No. 1/2005 (Part Two). Harare, Zimbabwe: International Maize and Wheat Improvement Center.

Lawal, J. O., \& Oluyole, K. A. (2008). Factors Influencing Adoption of Research Results and Agricultural Technologies among Cocoa Farming Households in Oyo State, Nigeria. International Journal of Sustainable Crop Production, 3(5), 10-12.

MAAIF (Ministry of Agriculture Animal Industry and Fisheries). (2010). Agriculture for Food and Income Security: Agricultural Sector Development Strategy and Investment Plan2010/11 - 2014/15. Entebbe, Uganda.

McDonald, H. J. (2009). Hand Book of Biological Statistics, (2nd ed.). Baltimore, Maryland: Sparky House Publishing.

MFPED (Ministry of Finance Planning and Economic Development). (2004). Poverty Eradication Action Plan (2004/5-2007/8). Kampala, Uganda.

Morris, M. L., Kelly, V. A., Kopicki, R. J., \& Byerlee, D. (2007). Fertilizer Use in African Agriculture: Lessons Learned and Good Practice Guidelines. Washington D.C.: The World Bank. http://dx.doi.org/10.1596/978-0-8213-6880-0

Mwaura, F., Adong, A., \& Okoboi, G. (2011). Membership to Farmer Groups in Uganda: Insights for Uganda Census of Agriculture 2008/9. Unpublished Report, EPRC. Kampala, Uganda.

Nayenga, R. N. (2008). Gender Dynamics in Agriculture in Uganda: What are the Key Policy Considerations? Kampala, Uganda: MFPED. 
Okello, B., \& Laker-Ojok, R. (2005). Wetland Diversity, Agricultural Productivity and Food Security in Uganda. In Omamo, S. W., Suresh, B., \& Temu, A. (Eds.), The Future of Smallholder Agriculture in Eastern Africa: The Roles of States, Markets and Civil Society, (pp. 25-81). Kampala, Ugand:. IFPRI Eastern Africa Food Policy Network.

Oluoch-Kosura, W. A., Marenya, P. P., \& Nzuma, M. J. (2002). Soil Fertility Management in Maize-Based Production Systems in Kenya. In Friesen, D. K., \& Palmer, A. F. E. (Eds.), Proceedings of the Seventh Eastern and Southern Africa Regional Maize Conference. Nairobi, Kenya.

Omotayo, O. E., \& Chukwuka, K. S. (2009). Soil fertility restoration techniques in sub-Saharan Africa using organic resources. African Journal of Agricultural Research, 4(3), 144-150. Retrieved from http://www.academicjournals.org/AJAR

Opio, F. (2003). Gender Mainstreaming in Agriculture with Special Reference to Uganda: Challenges and Prospects". In Proceedings of African Crop Sciences Conference, 6, 699-703.

Palm, C. A., Myres, R. K., \& Nandwa, S. M. (1997). Combined Use of Organic and Inorganic Nutrient Sources for Soil Fertility Maintenance and Replenishment. In Replenishing Soil Fertility in Africa. SSSA special publication, 51, 193-218.

Pender, J., Nkonya, E., Jagger, P., Sserunkuuma, D., \& Ssali, H. (2004). Strategies to Increase Agricultural Productivity and Reduce Land Degradation: Evidence from Uganda. Agricultural Economics, 31, 181-195.

Population Secretariat. (2010). Uganda Population Facts and National Development. Kampala, Uganda: MFPED. Retrieved

from http://www.popsec.org/documents/population_factors_and_national_development.pdf

Ransom, J. K., Paudyal, K., \& Adhikari, K. (2003). Adoption of Improved Maize Varieties in the Hills of Nepal. Agricultural Economics, 29(2), 299-305. http://dx.doi.org/10.1111/j.1574-0862.2003.tb00166.x

Roberts, R. K., \& Heady, E. O. (1982). Fertilizer Demand Function for Specific Nutrients Applied to Three Major U.S. Crops. Western Journal of Agricultural Economics, 265-289.

Roberts, T. L. (2009). The Role of Fertilizer in Growing the World's Food. Better Crops, 93(2). Retrieved from www.ipni.net/ppiweb/bcrops.nsf/\$webindex/.../BC09-2p12.pdf

Senoga, E. B., \& Matovu, J. M. (2010). Public Spending Composition and Public Sector Efficiency: Implications for Growth and Poverty Reduction in Uganda. Research Series 66. Kampala, Uganda: Economic Policy Research Centre.

Smaling, E., Toure, M., de Ridder, N., Saginga, N., \& Breman, H. (2006). Fertilizer use and the environment in Africa: friend or foes? Background Paper Prepared for the Africa fertilizer summit, Abuja.

Sserunkuuma, D. (2005).The Adoption and Impact of Improved Maize and Land Management Technologies in Uganda. Electronic Journal of Agricultural and Development Economics, 2(1), 67-84. Retrieved from www.fao.org/es/esa/eJADE

Sserunkuuma, D. (2007). Assessing the Potential for Spurring Agricultural Inputs Demand among Smallholders in Uganda through Institutional Innovations and Policy Changes. Research Report. Kampala, Uganda: Uganda Programme for Trade Opportunities and Policy.

Ssewanyana, S., \& Kasirye, I. (2010). Food Insecurity in Uganda: A Dilemma to Achieve the Hunger Millennium Development Goal. Research Series 70. Kampala, Uganda: Economic Policy Research Centre.

Strauss, J. J., Barbosa, M., Teixeira, S., Thomas, D., \& Gomes, R. J. (1991). Role of Education and Extension in the Adoption of Technology: A study of Upland Rice and Soybean Farmers in Central-West Brazil. Agricultural Economics, 5(4), 341-359. http://dx.doi.org/10.1016/0169-5150(91)90027-I

Tabi, A. J., Vabi M. B., \& Malaa, D. K. (2010). Adoption of Maize and Cassava Technologies in the Forest-Savannah Zone of Cameroon: Implications for Poverty Reduction. World Applied Sciences Journal, 11(2), 196-209.

Torero, M., \& Chowdhury, S. (2004). Increasing Access to Infrastructure for Africa's Rural Poor. 2020 Africa Conference Brief 16, Washington, D. C: IFPRI.

UBoS (Uganda Bureau of Statistics). (2006). Uganda National Household Survey: Socioeconomic Report. Kampala, Uganda.

UBoS. (2008). Uganda Census of Agriculture 2008/9: Enumerators' Instruction Manual. Kampala, Uganda. 
UBoS. (2010). Uganda National Household Survey: Socio-economic Module. Abridged Report. Kampala, Uganda.

Vanlauwe, B., \& Giller, K. E. (2006). Popular myths around soil fertility management in sub-Saharan Africa. Agriculture, Ecosystems \& Environment, 116(1-2), 34 - 46. http://dx.doi.org/10.1016/j.agee.2006.03.016

Wik, M., Kebede, T. A., Bergland, O., \& Holden, S. (2004). On the Measurement of Risk Aversion from Experimental Data. Discussion Paper D-16. Department of Economics and Resource Management, Agricultural University of Norway. Retrieved from citeseerx.ist.psu.edu/doi=10.1.1.196 